\title{
Accidental transplantation of bronchial carcinoma from a cadaver donor to two recipients of renal allografts
}

\author{
GB FORBES, MJ GOGGIN, FE DISCHE, IT SAEED, V PARSONS, \\ MJ HARDING, M BEWICK, AND CT RUDGE
}

From the Departments of Pathology and Renal Medicine, Kent and Canterbury Hospital, Canterbury CTI 3NG; the Departments of Pathology and Renal Medicine, King's College Hospital, London SE5; and the Renal Transplant Unit, Guy's Hospital, London SE1, UK

SUMMARY Malignancy was transferred inadvertently to two patients, each of whom received a renal transplant from a cadaver donor who was found at necropsy to have a small, clinically silent carcinoma of lung. Both recipients died with metastatic bronchial carcinoma of the same histological type as the donor's tumour. The literature on transplanted malignancy is reviewed.

It is generally accepted that recipients of transplanted organs are at greater risk of acquiring certain types of malignant disease compared with the agematched general population. Several factors are involved in post-transplantation oncogenesis, and these include the use of immunosuppressive drugs. ${ }^{12}$

Three categories of malignancy in transplant recipients are recognised. The most common is that which arises de novo, usually in the form of malignant lymphoma or skin cancer. In a follow-up study of renal transplant recipients, Kinlen et al. $^{3}$ have reported a 60 -fold increase in the incidence of nonHodgkin's lymphoma and an excess of squamouscell carcinoma of skin and mesenchymal tumours.

The second category relates to transplant recipients who are suffering from primary malignancy at the time of transplantation or who have been treated recently for malignant disease. The outcome in these cases depends upon a number of variables, especially the site and extent of the pre-existing cancer and the time interval between cancer removal and transplantation; according to Penn, ${ }^{2} 38 \%$ of 164 patients showed recurrence or metastasis of the original tumour and $6 \%$ developed de novo tumours. The prognosis was particularly poor in patients given liver transplantation.

The third category of malignancy, and the one with which we are concerned in this report, is that acquired by patients who receive allografts from donors who have cancer, either overt or undetected,

Accepted for publication 27 August 1980 at the time of donation. This is a raie but wellrecognised complication of transplantation, and Penn, ${ }^{2}$ drawing on a potential of over 20000 allograft recipients throughout the world, has collected 22 examples of cancer transmitted in this way.

Data on adequately documented cases, including the current study, are presented in Table 1 . The situation of the donor's primary growth was extrarenal in 15 , and bronchial carcinoma was the most frequent source. The donor kidney was the site of the primary tumour in five cases; two donors had frank renal carcinomas, and the recipients of these organs died of disseminated renal carconima. In three other donor kidneys, a small nodule in the cortex was biopsied and interpreted as a renal carcinoma of low-grade malignancy; partial or complete transplant nephrectomy was performed, and all three recipients survived with no evidence of recurrence. In all other cases the donated kidneys were of normal appearance to the naked eye. Disseminated malignancy was the cause of death, or a strong contributing factor, in 11 recipients, and the average survival time for these patients was 12 months after transplantation.

Both cadaver kidneys from the same donor were transplanted to two different recipients on three occasions; in two of the pairings transplanted malignancy was acquired by only one recipient, the other remaining well and free of cancer. We describe the development of metastatic carcinoma in two recipients of renal allografts from a cadaver donor who had a small bronchial carcinoma. We can find 
Table 1 Review of the literature

\begin{tabular}{|c|c|c|c|c|c|c|c|}
\hline \multirow[t]{2}{*}{ Author } & \multirow[t]{2}{*}{ Year } & \multicolumn{4}{|l|}{ Donor } & \multicolumn{2}{|l|}{ Recipient } \\
\hline & & Source & $\begin{array}{l}\text { Site of } \\
\text { primary } \\
\text { tumour }\end{array}$ & Metastases & $\begin{array}{l}\text { Gross } \\
\text { appearance } \\
\text { ofkidney }\end{array}$ & Extent of transmitted malignancy & Outcome \\
\hline $\begin{array}{l}\text { Martin } \\
\text { et al. }\end{array}$ & 1965 & Cadaver & Bronchus & + & Normal & $\begin{array}{l}\text { Bronchial carcinoma in allograft } \\
\text { and widespread metastases }\end{array}$ & $\begin{array}{l}\text { Death } 5 \text { months after } \\
\text { transplantation }\end{array}$ \\
\hline $\begin{array}{l}\text { McIntosh } \\
\text { et al. } .^{5}\end{array}$ & 1965 & Cadaver & $\begin{array}{l}\text { Pyriform } \\
\text { fossa } \\
\text { (epidermoid } \\
\text { carcinoma) }\end{array}$ & + & Normal & $\begin{array}{l}\text { Epidermoid carcinoma in } \\
\text { allograft and widespread } \\
\text { metastases }\end{array}$ & Death at 8 months \\
\hline $\begin{array}{l}\text { McLean } \\
\text { et al. }{ }^{\circ}\end{array}$ & 1965 & Cadaver & Breast & + & Normal & $\begin{array}{l}\text { Micrometastases of mammary } \\
\text { carcinoma in allograft } \\
\text { removed at } 5 \text { days }\end{array}$ & $\begin{array}{l}\text { Death from septicaemia at } 3 \\
\text { weeks }\end{array}$ \\
\hline $\begin{array}{l}\text { Wilson } \\
\text { et al.? }\end{array}$ & 1968 & Cadaver & Bronchus & + & Normal & $\begin{array}{l}\text { Bronchial carcinoma in allograft } \\
\text { and regional lymph nodes at } \\
18 \text { months. Allograft removed }\end{array}$ & $\begin{array}{l}\text { Residual carcinoma disappeared } \\
\text { after cessation of } \\
\text { immunotherapy. Alive and } \\
\text { well at } 2 \text { years }\end{array}$ \\
\hline $\begin{array}{l}\text { Muiznieks } \\
\text { et al. }\end{array}$ & 1968 & Cadaver & Thyroid & + & Normal & $\begin{array}{l}\text { Micrometastases of thyroid } \\
\text { carcinoma in allograft at } 7 \\
\text { days. Allograft removed }\end{array}$ & $\begin{array}{l}\text { Death at } 17 \text { months from } \\
\text { natural renal carcinoma. No } \\
\text { metastatic thyroid carcinoma } \\
\text { at necropsy }\end{array}$ \\
\hline $\begin{array}{l}\text { Zukoski } \\
\text { et al. }{ }^{\bullet}\end{array}$ & 1970 & Cadaver & Liver & + & Normal & $\begin{array}{l}\text { Metastatic hepatocarcinoma in } \\
\text { allograft and lungs at } 3 \text { years. } \\
\text { Allograft removed }\end{array}$ & $\begin{array}{l}\text { Pulmonary metastases } \\
\text { disappeared completely } 4 \\
\text { months after cessation of } \\
\text { immunotherapy. Died } \\
\text { postoperatively after further } \\
\text { transplant. No evidence of } \\
\text { tumour at necropsy. }\end{array}$ \\
\hline $\begin{array}{l}\text { Tunner } \\
\text { et al. } .^{10}\end{array}$ & 1971 & $\begin{array}{l}\text { Living } \\
\quad \text { (no relation) }\end{array}$ & Kidney & - & $\begin{array}{l}\text { Renal } \\
\text { carcinoma }\end{array}$ & $\begin{array}{l}\text { Allograft rejected but } \\
\text { transmitted tumour continued } \\
\text { to grow and invade locally }\end{array}$ & $\begin{array}{l}\text { Death from renal failure due to } \\
\text { polycystic kidneys at } 15 \\
\text { weeks }\end{array}$ \\
\hline $\begin{array}{l}\text { Cerilli } \\
\text { et al. }\end{array}$ & 1972 & $\begin{array}{l}\text { Living } \\
\text { (father) }\end{array}$ & Kidney & - & $\begin{array}{l}\text { Small renal } \\
\text { carcinoma } \\
\text { of } \\
\text { low-grade } \\
\text { malignancy }\end{array}$ & & $\begin{array}{l}\text { Allograft removed at } 2 \text { days. } \\
\text { Alive and well at } 17 \text { months }\end{array}$ \\
\hline $\begin{array}{l}\text { Jeremy } \\
\text { et al. } 12\end{array}$ & 1972 & Cadaver & $\begin{array}{l}\text { Malignant } \\
\text { melanoma }\end{array}$ & + & Normal & $\begin{array}{l}1 \text { Malignant melanoma in } \\
\text { allograft and widespread } \\
\text { metastases }\end{array}$ & Death at 11 months \\
\hline \multirow[t]{4}{*}{$\begin{array}{l}\text { Lanari } \\
\text { et al. }{ }^{13}\end{array}$} & 1972 & Cadaver & Bronchus & + & $\begin{array}{l}\text { Normal } \\
\text { (small } \\
\text { metastasis } \\
\text { in } \\
\text { contra- } \\
\text { lateral } \\
\text { kidney) }\end{array}$ & $\begin{array}{l}2 \text { No evidence of malignancy } \\
\text { Bronchial carcinoma in allograft } \\
\text { and regional lymph nodes }\end{array}$ & $\begin{array}{l}\text { Alive and well at } 3 \text { years } \\
\text { Death at } 16 \text { months from renal } \\
\text { failure, torulosis, and } \\
\text { transmitted carcinoma }\end{array}$ \\
\hline & & Cadaver & Bronchus & + & Normal & $\begin{array}{l}\text { Bronchial carcinoma in allograft, } \\
\text { lymph nodes, and liver }\end{array}$ & Death at 10 months \\
\hline & & Cadaver & Bronchus & + & Normal & $\begin{array}{l}\text { Small bronchial carcinoma in } \\
\text { biopsy of allograft. } \\
\text { Immunosuppression stopped }\end{array}$ & $\begin{array}{l}\text { Death at } 17 \text { months from } \\
\text { broncopneumonia. No } \\
\text { evidence of metastatic } \\
\text { carcinoma }\end{array}$ \\
\hline & & Cadaver & Breast & + & Normal & $\begin{array}{l}\text { Metastatic mammary carcinoma } \\
\text { in renal veins and lymphatics }\end{array}$ & $\begin{array}{l}\text { Death at } 16 \text { days from } \\
\text { postoperative complications. } \\
\text { No distant metastases }\end{array}$ \\
\hline $\begin{array}{l}\text { Mocelin } \\
\text { and } \\
\text { Brandina }^{14}\end{array}$ & 1975 & $\begin{array}{l}\text { Living } \\
\text { (father) }\end{array}$ & Kidney & $?$ & $\begin{array}{l}\text { Normal } \\
\text { (renal } \\
\text { carcinoma } \\
\text { in } \\
\text { nephrec- } \\
\text { tomy scar } \\
18 \text { months } \\
\text { after } \\
\text { donation) }\end{array}$ & $\begin{array}{l}\text { Renal carcinoma in allograft } \\
\text { and widespread metastases }\end{array}$ & Death at 10 months \\
\hline $\begin{array}{l}\text { Baird } \\
\text { et al. }\end{array}$ & 1975 & Cadaver & Kidney & - & $\begin{array}{l}\text { Small } \\
\text { nodule } \\
\text { found to } \\
\text { be renal } \\
\text { carcinoma }\end{array}$ & $\begin{array}{l}\text { Small renal carcinoma in } \\
\text { allograft widely excised }\end{array}$ & $\begin{array}{l}\text { Allograft rejected at } 44 \text { days. No } \\
\text { residual tumour. Well at } 18 \\
\text { months }\end{array}$ \\
\hline \multicolumn{2}{|c|}{$\begin{array}{l}\text { Wilson and } 1975 \\
\text { Penn' }\end{array}$} & $\begin{array}{l}\text { Living } \\
\quad \text { (parent) }\end{array}$ & Kidney & - & $\begin{array}{l}\text { Small } \\
\text { nodule } \\
\text { found to } \\
\text { be renal } \\
\text { carcinoma }\end{array}$ & $\begin{array}{l}\text { Carcinoma removed by partial } \\
\text { nephrectomy at } 3 \text { months }\end{array}$ & $\begin{array}{l}\text { Alive and well at } 3 \text { years. No } \\
\text { evidence of residual or } \\
\text { metastatic tumour }\end{array}$ \\
\hline
\end{tabular}




\begin{tabular}{|c|c|c|c|c|c|c|c|}
\hline \multirow[t]{2}{*}{ Author } & \multirow[t]{2}{*}{ Year } & \multicolumn{4}{|l|}{ Donor } & \multicolumn{2}{|l|}{ Recipient } \\
\hline & & Source & $\begin{array}{l}\text { Site of } \\
\text { primary } \\
\text { tumour }\end{array}$ & Metastases & $\begin{array}{l}\text { Gross } \\
\text { appearance } \\
\text { of kidney }\end{array}$ & Extent of transmitted malignancy & Outcome \\
\hline \multirow{3}{*}{$\begin{array}{l}\text { Barnes and } \\
\text { Fox }^{17}\end{array}$} & \multirow{3}{*}{1976} & Cadaver & Bronchus & $\begin{array}{l}\text { Not } \\
\text { recorded }\end{array}$ & $\begin{array}{l}\text { Not } \\
\text { recorded }\end{array}$ & $\begin{array}{l}\text { Widespread metastases of } \\
\text { bronchial carcinoma }\end{array}$ & Death at 5 months \\
\hline & & \multirow[t]{2}{*}{$\begin{array}{r}\text { Cadaver (no } \\
\text { necropsy) }\end{array}$} & \multirow[t]{2}{*}{$\begin{array}{l}\text { Uncertain } \\
\text { ? bronchus }\end{array}$} & \multirow[t]{2}{*}{+} & Normal & $\begin{array}{l}1 \text { Micrometastases in allograft } \\
\text { biopsy and widespread } \\
\text { metastases at } 5 \text { months }\end{array}$ & Death at 6 months \\
\hline & & & & & Normal & $\begin{array}{l}2 \text { Allograft removed because of } \\
\text { findings in recipient } 1 \text {. No } \\
\text { malignancy }\end{array}$ & Alive and well at 12 months \\
\hline $\begin{array}{l}\text { Gokel } \\
\text { et al. } .^{18}\end{array}$ & 1977 & Cadaver & $\begin{array}{l}\text { Chorio- } \\
\text { carcinoma }\end{array}$ & + & Normal & $\begin{array}{l}\text { Micrometastases in allograft and } \\
\text { high serum levels of human } \\
\text { chorionic gonadotrophin. } \\
\text { Allograft removed and } \\
\text { immunosuppression stopped }\end{array}$ & $\begin{array}{l}\text { HCG levels decreased and } \\
\text { disappeared at } 8 \text { weeks. } \\
\text { Committed suicide at } 7 \\
\text { months. No evidence of } \\
\text { malignancy }\end{array}$ \\
\hline $\begin{array}{l}\text { Peters and } \\
\text { Stuard }^{10}\end{array}$ & 1978 & Cadaver & $\begin{array}{l}\text { Malignant } \\
\text { melanoma }\end{array}$ & + & Normal & $\begin{array}{l}\text { Malignant melanoma in } \\
\text { allograft and widespread } \\
\text { metastases }\end{array}$ & Death at 20 months \\
\hline $\begin{array}{l}\text { Present } \\
\text { report }\end{array}$ & & Cadaver & Bronchus & - & Normal & $\begin{array}{l}1 \text { Bronchial carcinoma in } \\
\text { allograft and adrenal glands } \\
2 \text { Bronchial carcinoma in } \\
\text { allograft and widespread } \\
\text { metastases }\end{array}$ & $\begin{array}{l}\text { Death at } 15 \text { months } \\
\text { Death at } 20 \text { months }\end{array}$ \\
\hline
\end{tabular}

no record of a similar occurrence involving both recipients.

\section{The donor}

A 51-year-old man was admitted unconscious, having sustained a severe head injury with demonstrable cranial fractures. He failed to regain consciousness and died three days after admission. The relatives gave permission for removal of the kidneys for purposes of transplantation, and tests showed satisfactory histocompatibility between the donor and two prospective recipients (Table 2 ).

Necropsy confirmed the presence of multiple fractures of the skull, a large subdural haematoma, and small concussional haemorrhages in the brain. A small, ill-defined firm nodule, measuring $1.5 \mathrm{~cm}$ in diameter, was found at the periphery of the upper lobe of the right lung. As there was no obvious evidence of primary or metastatic malignancy this incidental finding was considered at the time to be a healed tuberculous focus, and it was removed for histological examination. Several days later sections of the nodule were examined microscopically, and these showed an anaplastic bronchial carcinoma of mixed fusiform and pleomorphic cell type (Fig. 1). There was a background of necrotic fibrous tissue with much carbon pigment, and the overall appearance suggested that the tumour had arisen in an

Table 2 Histocompatibility tests

\begin{tabular}{llllll}
\hline & Blood group & HLA group \\
\hline Donor & $0+$ & $\mathbf{A}_{1}$ & $\mathbf{A}_{\mathbf{2}}$ & $\mathbf{B}_{\mathbf{3}}$ & $\mathbf{B}_{\mathbf{8}}$ \\
Recipient 1 & $0-$ & $\mathbf{A}_{1}$ & $\mathbf{A}_{2}$ & $\mathbf{B}_{\mathbf{8}}$ & $\mathbf{B}_{12}$ \\
Recipient 2 & $0+$ & $\mathbf{A}_{2}$ & $\mathbf{A}_{10}$ & $\mathbf{B}_{\mathbf{8}}$ & $\mathbf{B}_{12}$ \\
\hline
\end{tabular}

inactive tuberculous lesion ('scar' carcinoma of lung). Although the growth was small it showed bizarre giant nuclei and considerable mitotic activity, indicating a highly malignant potential. This finding was communicated to the surgeons responsible for the

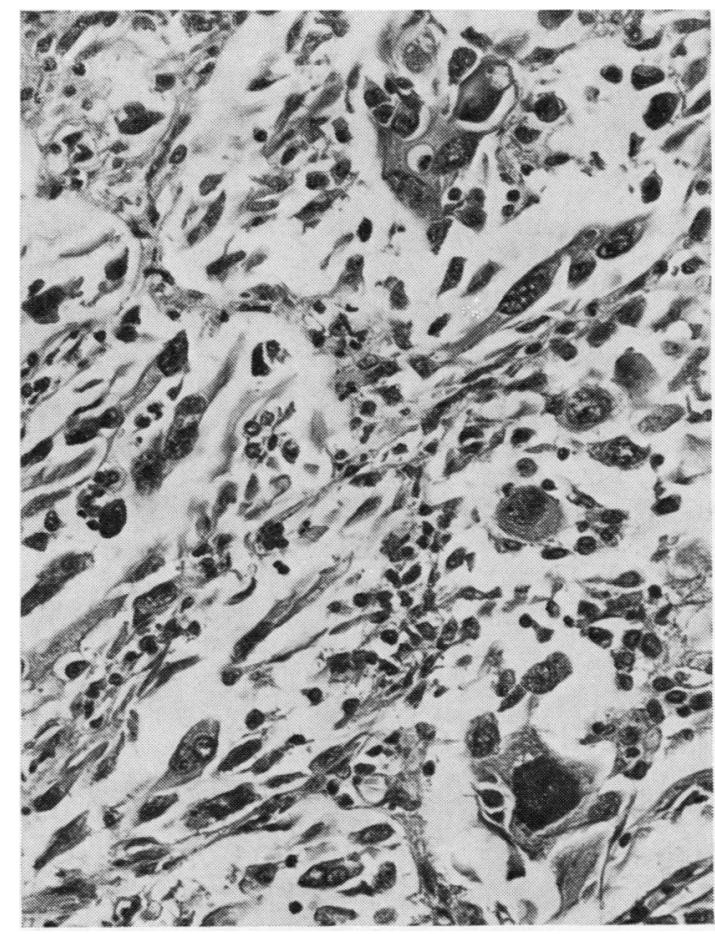

Fig. 1 The tumour in the donor's lung. $\times 280$. 
care of the donor but by a regrettable oversight the renal unit and transplant surgeon were not informed.

The donor had been a moderately heavy cigarette smoker for many years.

\section{Recipient 1}

A 53-year-old housewife presented with end-stage renal failure and hyperparathyroidism in 1973 and haemodialysis was started in 1974. In December 1977 renal transplantation was carried out using the donor's right kidney. She was immunosuppressed with azathioprine and a reducing dose of prednisolone from $200 \mathrm{mg}$ daily initially to $10 \mathrm{mg}$ daily at three months.

She remained well for 13 months but had to be readmitted with deteriorating renal function. Intravenous urography and subsequent operation showed extensive obstruction of the donor ureter and this was bypassed with a loop of small bowel. A biopsy specimen from the transplant kidney showed features consistent with chronic rejection and also a patchy infiltrate of abnormal pleomorphic cells suggestive of neoplasia. Her condition deteriorated and she died 15 months after receiving the transplant.

At necropsy the transplanted kidney was enlarged and globular in shape. The cortex was swollen

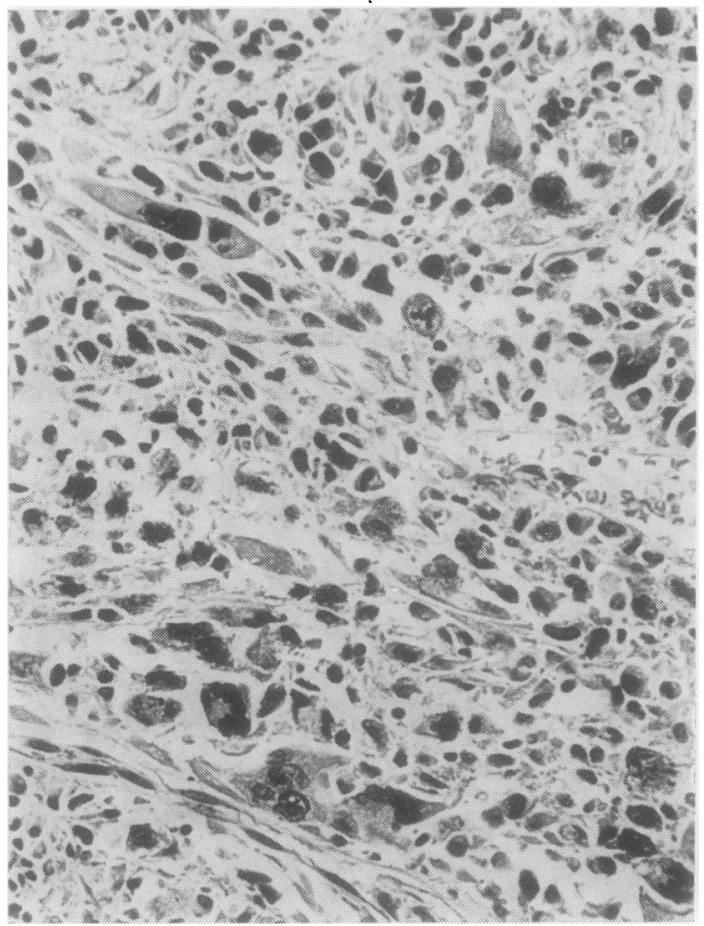

Fig. 2 Tumour in kidney transplanted to recipient $1 . \times 280$. and pale and it contained two tumour-like lesions, the larger measuring $4 \mathrm{~cm}$ in diameter. Several of the papillae were necrotic, and the renal pelvis was dilated and acutely inflamed.

Both natural kidneys were small, the left organ weighing $36 \mathrm{~g}$ and the right $45 \mathrm{~g}$. The capsules were thickened and the cortical surfaces were finely granular. Other salient features were marked left ventricular hypertrophy and greatly enlarged parathyroid glands, one of which was calcified. The medulla of both adrenal glands contained deposits of tumour-like tissue similar to those seen in the renal cortex of the transplanted kidney.

Histological examination of the neoplastic tissue in the transplant kidney and in both adrenal glands showed an anaplastic tumour composed of fusiform and pleomorphic cells with much nuclear atypism and mitotic activity (Fig. 2).

\section{Recipient 2}

A 39-year-old man presented in 1974 with end-stage renal failure and hypertension which necessitated haemodialysis. He received the donor's other kidney in December 1977. Immunosuppression therapy was the same as that given to recipient 1 . A brain abscess developed, and this responded to antibiotic therapy,

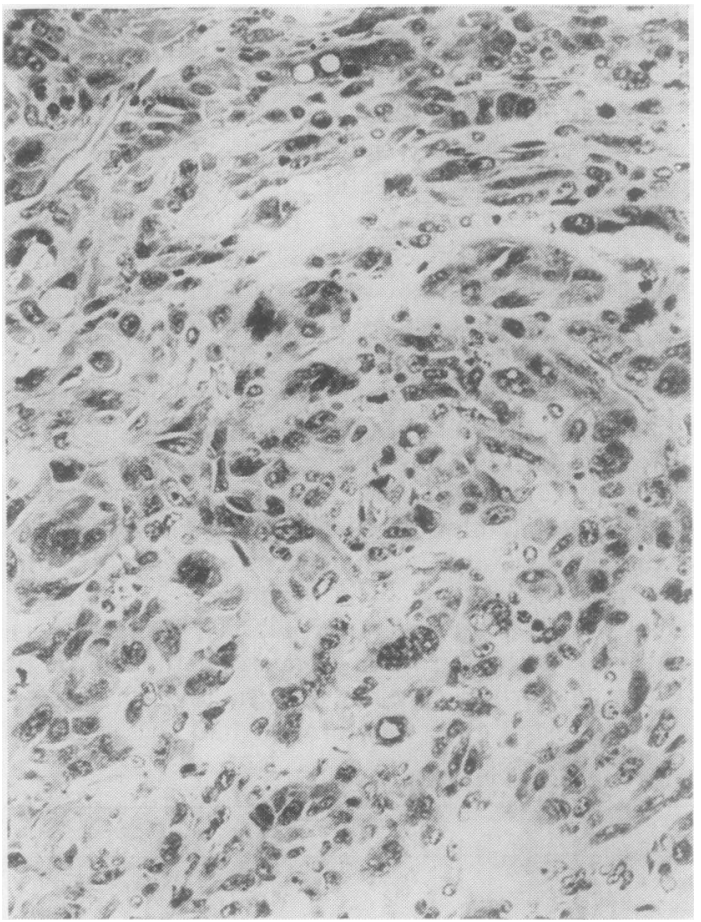

Fig. 3 Tumour in kidney transplanted to recipient $2 . \times 280$. 


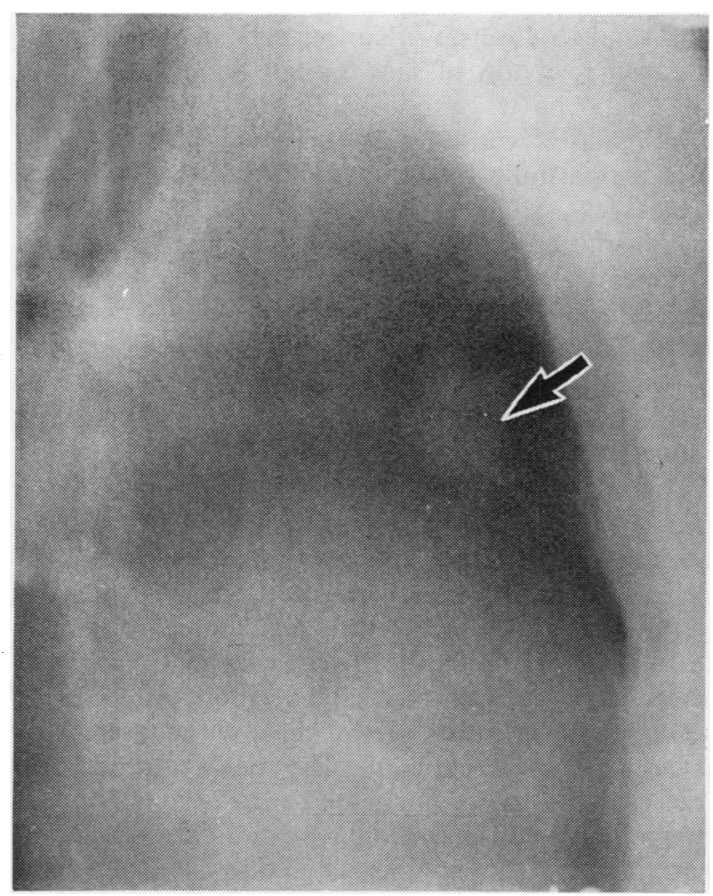

Fig. 4 Tomograph showing metastatic deposit (arrowed) in upper lobe of left lung of recipient 2.

but afterwards there was a gradual deterioration of graft function. A transplant arteriogram showed multiple stenosis of the major branch arteries and extensive occlusion and non-filling of the smaller arteries compatible with chronic rejection (see Downes $^{20}$ for further details). Haemodialysis was restarted and at the same time azathioprine was discontinued and the steroid dosage was reduced. The transplanted organ was removed on 7 June 1979.

The kidney measured $10 \times 6.5 \times 7.5 \mathrm{~cm}$ and contained numerous ill-defined tumour masses of greyish-yellow colour in both the cortex and the medulla. The largest mass measured $8 \mathrm{~cm}$ in main dimension and it projected outwards through the capsule. Histological examination showed multiple tumours composed for the most part of sheets of undifferentiated pleomorphic cells and, in addition, collections of fusiform and polygonal cells with bizarre nuclei (Fig. 3); the tumour invaded glomeruli, tubules, and blood vessels including the renal vein. Non-neoplastic areas showed the features of chronic rejection.

Lesions with the typical radiological features of metastatic deposits were found in the sixth left rib on the postero-anterior film and in the upper lobe of the left lung on tomography (Fig. 4). After the cessation of steroid therapy the lung lesion regressed, and it

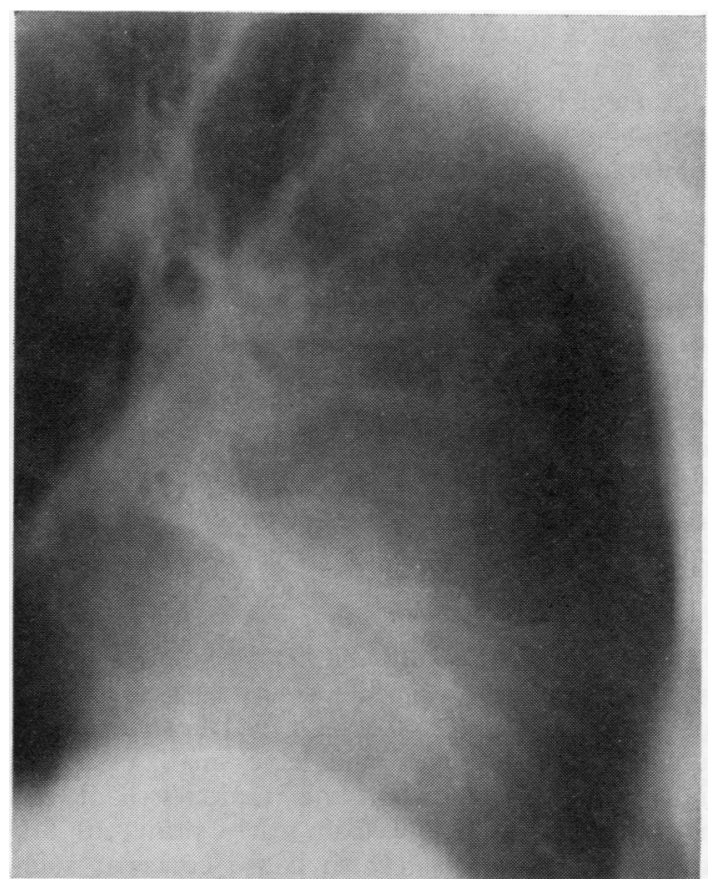

Fig. 5 Disappearance of metastasis six weeks after stopping immunosuppressive therapy.

disappeared completely six weeks later (Fig. 5). The patient's general health deteriorated, however, and he died on 5 August 1979, 20 months after transplantation.

At necropsy a large mass of malignant tissue was found at the site of the removed transplant kidney, and there was extensive metastatic involvement of the peritoneum in the form of multiple tumour nodules measuring up to $4 \mathrm{~cm}$ in diameter. The liver contained two small metastatic deposits, and there was also a deposit in the sixth left rib. There was no evidence of residual metastasis in the upper lobe of the left lung. The natural kidneys were severely reduced in size and consisted of a narrow rim of renal tissue surrounding excess of pelvic fat. The cortical surfaces were slightly granular.

Microscopic examination of the residual tumour at the transplant nephrectomy site and of the deposits in the peritoneum, liver, and sixth rib showed the same histological features as were seen in sections of the transplant kidney removed previously from this patient.

When sections of the tumour were compared with those of the other recipient's tumour a resemblance in cell morphology was noted, and this similarity prompted a review of the necropsy findings in the donor. It then became apparent that the tumours in 
the donor's lung and in both allografts were of the same nature, and it seemed logical to conclude that micrometastases in the donor's kidneys, already present at the time of transplantation, had grown uninhibited in the two immunosuppressed recipients.

\section{Discussion}

There can be little doubt that the recipients' tumours were acquired by implantation of cancer cells via the allografts. Sections were circulated to several experts in the field of tumour pathology, and there was general agreement that the histological appearance of all three tumours was compatible with anaplastic bronchial carcinoma when allowance was made for the fact that the tumours were growing in three different hosts, two of whom had received immunosuppressive therapy.

Patients dying of malignant disease confined to the brain are the only cancer subjects who should be considered as sources of organs for transplantation. Some donors, however, will have small, clinically undetectable carcinomas, and tumours liable to metastasise systemically from early primaries are among those most likely to cause concern; such tumours include bronchial carcinoma, mammary carcinoma, malignant melanoma, and choriocarcinoma.

In order to exclude the possibility of unsuspected malignancy, necropsy should be carried out on cadaver donors as soon as possible after removal of the kidneys. If a suspicious lesion is encountered, rapid histological diagnosis should be obtained. In addition, the kidneys should be inspected carefully by the transplant surgeon; micrometastases will not, of course, be detected in this way, but if a tumourlike nodule is observed it should be excised for frozen-section examination.

When a kidney has already been transplanted and there is suspicion that cancer cells may have been implanted with it, steps may be taken to reduce the possibility of the development of metastases. The suspect kidney may be removed, but the timing of removal will depend on a number of factors: these will include the age, clinical status, and attitude of the recipient, the degree of rejection already taking place, the nature of the tumour in the donor, and any evidence of its presence in the graft. It should be remembered that not all recipients of allografts from cancer patients will suffer the fate of our patients: of 65 recipients of organs from donors who were known to be suffering from some form of extracerebral cancer at the time of donation, approximately onethird developed neoplasia of the same histological type as in the original donor $;^{2}$ the remainder showed no evidence of transmitted cancer. This can be attributed to absence of cancer cells in the allograft or rapid rejection of any foreign neoplastic clones that may have been introduced. In theory, the latter reaction would be more likely if there was poor histocompatibility between the donor and recipient tissues.

Transmitted tumour in the host may regress and disappear after the graft has been removed and immunosuppressive therapy discontinued. This satisfactory result has been the subject of reports by Wilson et al., ${ }^{7}$ Zukoski et al., ${ }^{9}$ and Gokel et al. ${ }^{18}$ (see Table 1); partial regression of tumour occurred in our second patient.

These and other factors must be weighed up by the clinician and the patient together when deciding on the action to be taken. It may be that the patient will elect to take the calculated risk of keeping the allograft in the hope that the transplanted kidney is cancer-free or that his own defences will eliminate any cancer cells that may have been engrafted. ${ }^{21}$

Our findings throw light on the behaviour of carcinoma in respect of embolisation of tumour cells. The lesion in the donor's lung measured $1.5 \mathrm{~cm}$ in its main axis, but histological examination showed that most of the nodule was composed of fibrocaseous tissue and that the cancer itself was of little more than microscopic proportions. Subsequent events showed that even this minute tumour had already metastasised.

\section{References}

${ }^{1}$ Sheil AGR. Transplantation and cancer. In: Morris PJ, ed. Kidney transplantation: principles and practice. London: Academic Press, 1979:335-52.

2 Penn I. Tumours arising in organ transplant recipients. Adv Cancer Res 1978;28:31-61.

${ }^{3}$ Kinlen LJ, Sheil AGR, Peto J, Doll R. Collaborative United Kingdom-Australasian study of cancer in patients treated with immunosuppressive drugs. $\mathrm{Br} \mathrm{Med}$ $J$ 1979;2:1461-6.

${ }^{4}$ Martin DC, Rusini M, Rosen VJ. Cadaveric renal homotransplantation with inadvertent transplantation of carcinoma. JAMA 1965;192:82-4.

${ }^{5}$ McIntosh DA, McPhaul JJ, Peterson EW, Smith JR, Cook FE, Humphreys JW. Homotransplantation of a cadaver neoplasm and a renal homograft. JAMA 1965; 192:1171-3.

${ }^{6}$ McLean LD, Dosseter JB, Gault MH, Oliver JA, Inglish FG, MacKinnon KJ. Renal homotransplantation using cadaver donors. Arch Surg 1965;91:288-304.

7 Wilson RE, Hager GB, Hampers CL, Corson JM, Merrill JP, Murray JE. Immunologic rejection of human cancer transplanted with a renal allograft. $N$ Engl J Med 1968; 278:479-83.

${ }^{8}$ Muiznieks HW, Berg JW, Lawrence W, Randall HT. Suitability of donor kidneys from patients with cancer. Surgery $1968 ; 64: 871-7$.

- Zukoski CF, Killen DA, Ginn E, Matter B, Lucas DO, Seigler HF. Transplanted carcinoma in an immunosuppressed patient. Transplantation 1970;9:71-4. 
10 Tunner WS, Goldsmith EJ, Whitsell JC. Human homotransplantation of normal and neoplastic tissue from the same organ. $J$ Urol $1971 ; 105: 18-20$.

${ }^{11}$ Cerilli GT, Nelsen C, Dorfmann L. Renal homotransplantation in infants and children with the haemolyticuremic syndrome. Surgery $1972 ; 71: 66-71$.

12 Jeremy D, Farnsworth RH, Robertson MR, Annetts DL, Murnaghan GF. Transplantation of malignant melanoma with cadaver kidney. Transplantation 1972;13: 619-20.

${ }^{13}$ Lanari A, Rodo JE, Barcat JA, et al. Cuatro casos de desarrollo de un cancer del dador en el rinon injertado. Medicina (B Aires) 1972;32:79-92.

${ }^{14}$ Mocelin AJ, Brandina L. Inadvertent transplant of a malignancy (letter). Transplantation 1975;19:430.

${ }^{15}$ Baird RN, White HJO, Tribe CR. Renal carcinoma in a cadaver kidney graft donor. Br Med J 1975;2:371.

${ }^{16}$ Wilson RE, Penn I. Fate of tumours transplanted with a renal allograft. Transplant Proc 1975;7:327-31.
17 Barnes AD, Fox M. Transplantation of tumour with a kidney graft. $\mathrm{Br}$ Med J 1976;1:1442-4.

${ }^{18}$ Gokel JM, Rjosk HK, Meister P, Stelter WJ, Witte J. Metastatic choriocarcinoma transplanted with cadaver kidney. Cancer 1977;3:1317-21.

19 Peters MS, Stuard ID. Metastatic malignant melanoma transplanted via a renal homograft. Cancer 1978;41: 2426-30.

${ }^{20}$ Downes MO. Transplant of a kidney containing an occult metastasis. Br J Radiol 1980;53:908-9.

${ }^{21}$ Henry JA. In: Anderton JL, Parsons FM, Jones DE, eds. Living with renal failure. Lancaster: MTP Press, 1978: 215-21.

Requests for reprints to: Dr GB Forbes, Department of Pathology, Kent and Canterbury Hospital, Canterbury, Kent CT1 3NG. 